\title{
RENAL FUNCTION STUDIES IN TOXEMIA OF PREGNANCY
}

\author{
EXCRETION OF SOLUTES AND RENAL HEMODYNAMICS DURING \\ OSMOTIC DIURESIS IN HYDROPENIA ${ }^{2}$
}

\author{
By N. S. ASSALI, S. A. KAPLAN, S. J. FOMON, AND R. A. DOUGLASS, JR., \\ WITH THE TECHNICAL ASSISTANCE OF R. SUYEMOTO
(From the Departments of Obstetrics and Pediatrics and the Children's Hospital Research Foundation, the University of Cincinnati College of Medicine and the Cincinnati \\ General Hospital, Cincinnati, Ohio)
}

(Submitted for publication April 28, 1952; accepted October 22, 1952)

The occurrence of proteinuria and the repeated demonstration of depression of filtration rate and renal plasma flow in toxemia of pregnancy are evidence that there is impairment of renal function. Structural abnormalities are not demonstrable in pre-eclampsia although when the stage of eclampsia supervenes morphologic abnormalities are occasionally detectable $(1,2)$. The invariable presence of edema attests to the fact that the functional lesion involves the mechanism of excretion of water and solutes.

Attempts to define the mechanism of retention of fluid in toxemia of pregnancy have been directed mainly at the hormonal balance of toxemic subjects (3). Investigations focused specifically on the renal mechanism of water and electrolyte excretion and carried out under standard and reproducible conditions have not been reported.

The present investigation was undertaken to apply some of the recently acquired knowledge of the relationship between excretion of water and solutes under the specific conditions of osmotic diuresis in hydropenia to patients with toxemia of pregnancy. The relationship between excreted loads of electrolytes and other urinary constituents, on the one hand, and water on the other, is predictable and reproducible in normal pregnant and non-pregnant subjects studied with this technique (4-6). It has been observed that the amount of water excreted under these conditions is determined solely by the osmotic pressure of the excreted solutes, that the concentrations of sodium and chloride in the urine are remarkably constant and independent of the rate of urine flow, and that the rates of excretion of sodium and

1 This investigation was supported (in part) by research grants from the National Heart Institute, the National Institutes of Health, Public Health Service. chloride are directly proportional to the rate of excretion of the total load of solutes. It was thought that if the technique of osmotic diuresis in hydropenia were applied to cases of toxemia of pregnancy, deviations from the normal pattern might be observed and that these deviations might shed additional light on the nature of the renal defect and the mechanism of edema formation in this disease.

In contrast to the paucity of reports on the renal handling of electrolytes in toxemia, the renal circulation in this disease has undergone much study (7-18). Most of the investigations were carried out after the initiation of therapy, and many either postpartum or after the acute phase of illness had subsided and edema and proteinuria were no longer present. The lack of uniformity of basal conditions in different studies probably accounts for some of the difference of opinion concerning the degree of impairment of renal hemodynamics. Accordingly, the present studies were planned with a view to measuring renal hemodynamics in the acute phase of the illness without the introduction of complicating factors such as therapy or delivery.

The studies were extended to include also cases of essential hypertension in patients in the last trimester of pregnancy. It was thought of interest to apply the aforementioned techniques to cases of this syndrome which resembles to a certain extent the syndrome of toxemia of pregnancy.

\section{MATERIAL AND METHODS}

Eight patients with pre-eclampsia, 2 with eclampsia and 4 with essential hypertension associated with pregnancy, were studied. The diagnosis of pre-eclampsia was based on the presence of hypertension, edema and proteinuria after the 24th week of gestation, together with the absence of a history of hypertension prior to pregnancy, and the 
return of the blood pressure to normal levels following delivery. The diagnosis of eclampsia was made when these findings were associated with convulsions and coma. One eclamptic patient (R. K.) had underlying hydronephrosis of the right kidney which required nephrectomy two months after delivery. The four hypertensive patients had persistent hypertension prior to pregnancy. Hypertension was also observed in the early part of pregnancy and was not aggravated during the last trimester. Clinical data on the patients studied are given in Table I. All patients were kept at bed rest from the time of admission until completion of the loading procedure. None of the patients was in labor at the time of study.

Since an attempt was made to investigate their renal function in the acute stage, the patients with pre-eclampsia and essential hypertension received no specific therapy prior to the procedure. The majority underwent the study within 24 hours of admission to the hospital. There was no evidence that any of the patients was experiencing spontaneous diuresis prior to the procedure.

The two eclamptic patients received, on admission, doses of veratrum and magnesium sulfate sufficient to control convulsions and ameliorate their symptoms. After convulsions had been controlled, treatment was temporarily discontinued, and the blood pressure was allowed to return to previous hypertensive levels. In both patients the hypertension, edema and proteinuria were still present during the study.

Osmotic diuresis was induced in hydropenia by administration of hypertonic mannitol solution according to the method previously described (6). Urine was collected during the "resting state" and over two or more periods of 10 to 15 minutes following induction of diuresis. Samples of blood were drawn close to the midpoint of each period. Urine and blood were analyzed for their content of mannitol, para-aminohippurate (PAH), sodium, chloride and potassium according to methods in routine use in these laboratories (4). Effective osmotic activity of the urine was determined by measurement of the freezing point depression.

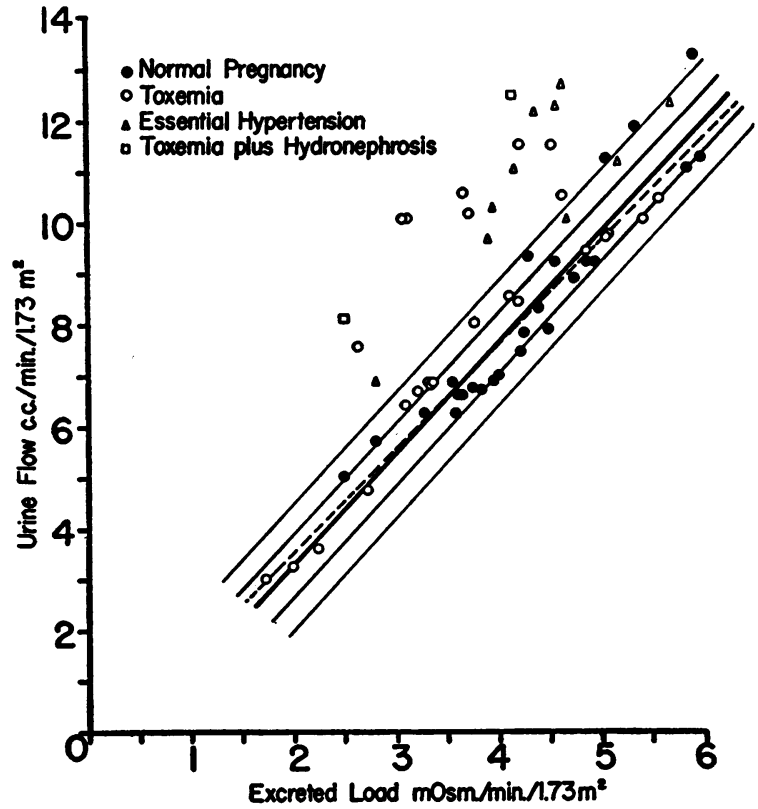

Fig. 1. Urine Flow vs. Excreted Load (See Text)

\section{RESULTS}

Figure 1 is a plot of urine flow versus excreted load. The closed circles refer to measurements made on a group of normotensive subjects who were in the last trimester of pregnancy. Some of these data have been reported previously (6) and others were obtained in further studies. Each plotted point refers to a urine collection period. The heavy continuous line is the regression line calculated from the points referring to normal pregnant patients and the two lighter lines represent plus and minus one and two standard er-

TABLE I

Clinical data

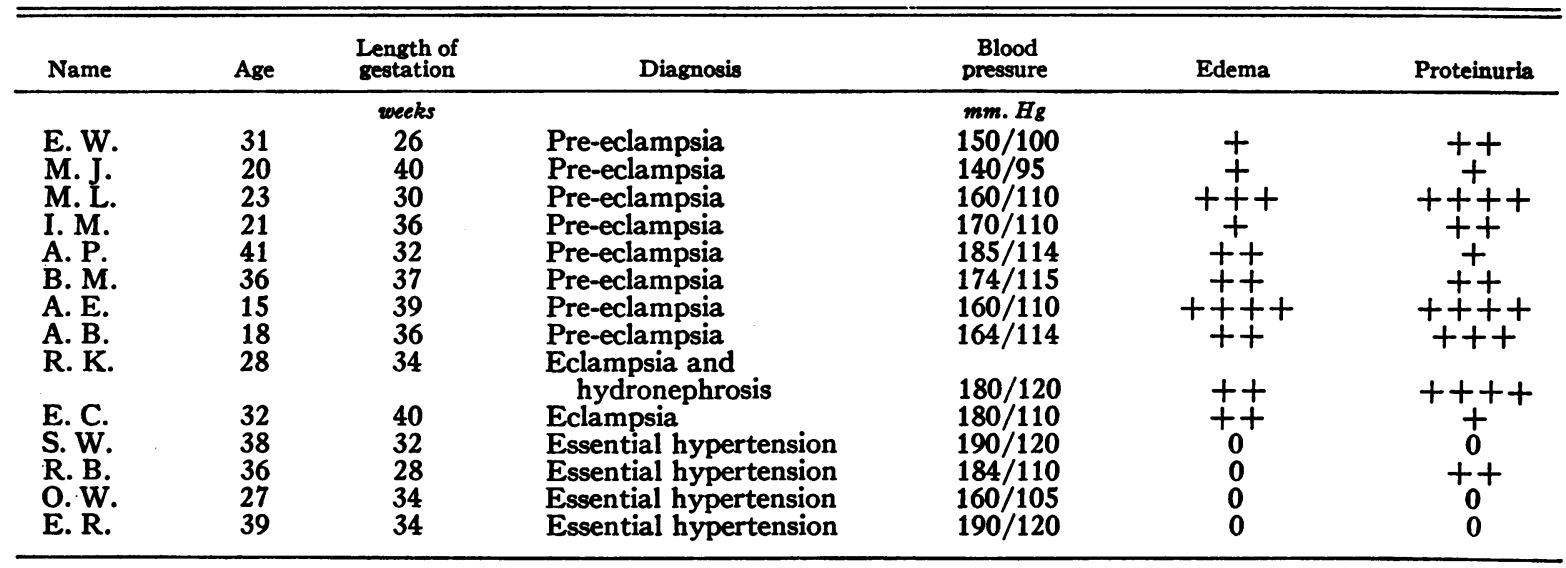


rors of the estimate of the regression equation. The open circles refer to urine collection periods from patients with toxemia and the open triangles to urine collections from patients with essential hypertension in pregnancy. The interrupted line is the regression line from the data of Brodsky (5) who subjected 16 normal non-pregnant individuals to osmotic diuresis under conditions identical with those described in this paper. There is a close correlation between the relationship of flow and load in the two groups of normal cases suggesting that patients with normal preg- normal and abnormal groups in terms of excretion of water per unit of solute load.

Figure 2 is a plot of $\mathrm{Na}$ loss vs. excreted load. The symbols are the same as in Figure 1. Once more the regression line, plus and minus one and two standard errors of the estimate for the normotensive pregnant patients has been included as well as the regression line calculated from the data of Brodsky (5) for normotensive non-pregnant patients. The fact that the regression line for the normal non-pregnant patients falls outside the line representing one standard error of the

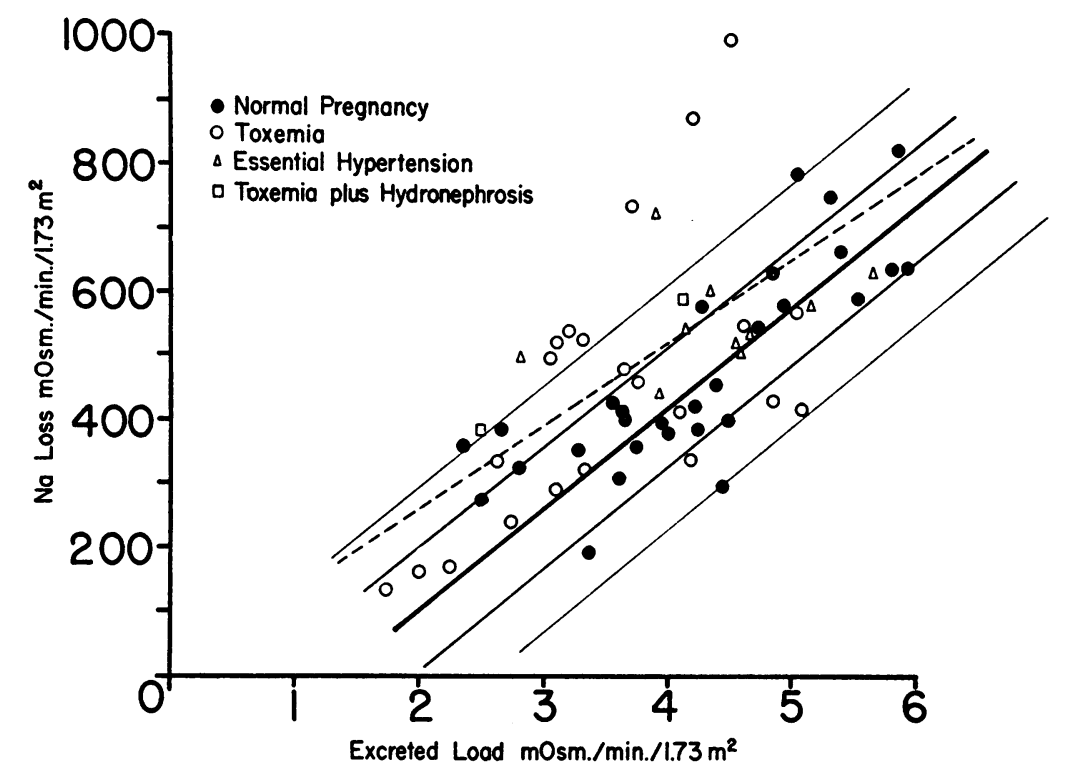

Fig. 2. Sodium Excretion vs. Excreted Load

The three open circles falling well to the left of the line indicating \pm 2 S.E. refer to a single patient with toxemia of pregnancy. All other points fall either between or close to the lines indicating \pm 2 S.E. (See text.)

Note: The ordinate of this figure should read $\mu O \mathrm{sm} . / \mathrm{min} . / 1.73 \mathrm{~m}^{2}$ instead of $\mathrm{mOsm} . / \mathrm{min} . / 1.73 \mathrm{~m}^{2}$, as it now appears.-Author.

nancy do not have any abnormality in their ability to conserve water under hydropenic conditions.

The open circles and triangles refer to measurements obtained in cases of toxemia and essential hypertension in pregnancy. It is evident that any point falling to the left of the normal line indicates that the given load requires or has available a greater than normal quantity of water for its excretion. The majority of points referring to cases of abnormal pregnancy fall outside the line demarcating 2 S.E. of the estimate indicating that there is a significant difference between the estimate for the normotensive pregnant patients would seem to indicate that in normal pregnancy there is some tendency for lower rates of excretion of $\mathrm{Na}$ per unit of total excreted load, but the significance of this observation is not apparent. The majority of points for the abnormal cases do not deviate widely from the regression lines calculated from the data of the normal non-pregnant and pregnant subjects, indicating that there is no material difference between the rate of loss of $\mathrm{Na}$ per unit of total solutes excreted in normal cases and cases of toxemia or hypertension. The rela- 
TABLE II

Mannitol and PAH clearances and filtration fractions of hypertensive and toxemic cases

\begin{tabular}{|c|c|c|c|c|}
\hline Patient* & Diagnosis & $\begin{array}{l}\text { Mannitol } \\
\text { clearance }\end{array}$ & $\underset{\text { clearance }}{\text { PAH }}$ & $\begin{array}{c}\text { Filtration } \\
\text { fraction }\end{array}$ \\
\hline $\begin{array}{l}\text { E. W. } \\
\text { E. C. } \\
\text { M. J. } \\
\text { M. L. } \\
\text { I. M. } \\
\text { A. P. } \\
\text { B. M. } \\
\text { A. E. } \\
\text { A. B. } \\
\text { S. W. } \\
\text { R. B. } \\
\text { O. W. } \\
\text { E. R. }\end{array}$ & $\begin{array}{c}\text { Toxemia } \\
\text { Toxemia } \\
\text { Toxemia } \\
\text { Toxemia } \\
\text { Toxemia } \\
\text { Toxemia } \\
\text { Toxemia } \\
\text { Toxemia } \\
\text { Toxemia } \\
\text { Essential hyperten. } \\
\text { Essential hyperten. } \\
\text { Essential hyperten. } \\
\text { Essential hyperten. }\end{array}$ & $\begin{array}{c}c c . / m i n . / 1.73 m .2 \\
57 \\
101 \\
100 \\
89 \\
76 \\
70 \\
55 \\
84 \\
60 \\
65 \\
62 \\
95 \\
95\end{array}$ & $\begin{array}{c}c . / m i n . / 1.73 m .{ }^{2} \\
441 \\
427 \\
725 \\
749 \\
443 \\
699 \\
402 \\
502 \\
623 \\
410 \\
292 \\
420 \\
564\end{array}$ & $\begin{array}{l}0.13 \\
0.24 \\
0.14 \\
0.13 \\
0.17 \\
0.10 \\
0.14 \\
0.17 \\
0.10 \\
0.16 \\
0.21 \\
0.23 \\
0.17\end{array}$ \\
\hline \multicolumn{2}{|c|}{$\begin{array}{l}\text { Mean of } 9 \text { patients with toxemia } \\
\text { Mean of } 4 \text { patients with essential hypertension } \\
\text { Mean of } 7 \text { normal pregnancies }\end{array}$} & $\begin{array}{r}77 \\
79 \\
109\end{array}$ & $\begin{array}{l}557 \\
422 \\
699\end{array}$ & $\begin{array}{l}0.144 \\
0.191 \\
0.157\end{array}$ \\
\hline
\end{tabular}

* Patient R. K. was not included because she had underlying hydronephrosis. Her mannitol clearance was 33 and her PAH clearance was $236 \mathrm{cc} . / \mathrm{min} . / 1.73 \mathrm{~m}^{2}$.

tionship of chloride loss to excreted load resembled closely that for sodium.

Table II presents the mannitol and PAH clearances and filtration fractions of the two groups of abnormal pregnancies, comprising nine cases of toxemia and four of essential hypertension. (R. K., who had eclampsia with underlying hydronephrosis, is excluded.) Each figure is the average of 2 or 3 urine collection periods. The means of the clearances of mannitol and PAH for each group were reduced when compared with the means for the group of seven cases of normal pregnancy. Calculation of the significance of the differences between these means has been made by computating Student's $t$ for each pair of values according to the method of Fisher (19). GFR was significantly reduced as compared with the normal both in the toxemic $(p=0.002)$ and in the hypertensive ( $p=0.018)$ group; RPF was also reduced in both groups $(p=0.054$ and $p=0.008$, respectively). It was not possible to demonstrate any significant difference between the group with essential hypertension and that with toxemia.

Table III presents renal vascular resistances

TABLE III

Renal vascular resistances in cases with toxemia and hypertension Values are given in dynes sec. $\mathrm{cm} .^{-b}$

\begin{tabular}{|c|c|c|c|c|c|}
\hline Patient & Diagnosis & $\begin{array}{l}\text { Total renal } \\
\text { resistance }\end{array}$ & $\begin{array}{c}\text { Afferent } \\
\text { resistance }\end{array}$ & $\begin{array}{l}\text { Efferent } \\
\text { resistance }\end{array}$ & $\begin{array}{l}\text { Venular } \\
\text { resistance }\end{array}$ \\
\hline $\begin{array}{l}\text { E. W. } \\
\text { E. C. } \\
\text { M. J. } \\
\text { M. L. } \\
\text { I. M. } \\
\text { A. P. } \\
\text { B. M. } \\
\text { A. E. } \\
\text { A. B. } \\
\text { S. W. } \\
\text { R. B. } \\
\text { O. W. } \\
\text { E. L. }\end{array}$ & $\begin{array}{l}\text { Toxemia } \\
\text { Toxemia } \\
\text { Toxemia } \\
\text { Toxemia } \\
\text { Toxemia } \\
\text { Toxemia } \\
\text { Toxemia } \\
\text { Toxemia } \\
\text { Toxemia } \\
\text { Ess. hyp. } \\
\text { Ess. hyp. } \\
\text { Ess. hyp. } \\
\text { Ess. hyp. }\end{array}$ & $\begin{array}{r}8,181 \\
13,869 \\
6,813 \\
7,459 \\
10,469 \\
10,100 \\
13,924 \\
13,499 \\
8,373 \\
16,408 \\
19,920 \\
12,922 \\
11,368\end{array}$ & $\begin{array}{r}4,267 \\
9,332 \\
3,953 \\
4,834 \\
6,713 \\
6,971 \\
9,748 \\
8,895 \\
5,289 \\
11,929 \\
13,633 \\
8,166 \\
7,763\end{array}$ & $\begin{array}{l}1,223 \\
2,217 \\
1,283 \\
1,105 \\
1,534 \\
1,143 \\
1,260 \\
1,870 \\
1,010 \\
1,567 \\
1,942 \\
2,091 \\
1,572\end{array}$ & $\begin{array}{l}2,691 \\
2,320 \\
1,577 \\
1,519 \\
2,231 \\
1,986 \\
2,917 \\
2,734 \\
2,075 \\
2,912 \\
4,345 \\
2,665 \\
2,033\end{array}$ \\
\hline \multicolumn{2}{|c|}{$\begin{array}{l}\text { Mean of } 9 \text { patients with toxemia } \\
\text { Mean of } 4 \text { patients with ess. hyp. } \\
\text { Mean of } 7 \text { normal pregnancies }\end{array}$} & $\begin{array}{r}10,229 \\
15,154 \\
5,178\end{array}$ & $\begin{array}{r}6,666 \\
10,397 \\
1,883\end{array}$ & $\begin{array}{l}1,405 \\
1,793 \\
1,531\end{array}$ & $\begin{array}{l}2,228 \\
2,989 \\
1,751\end{array}$ \\
\hline
\end{tabular}


calculated from the values for the mean arterial blood pressure, RBF, GFR, hematocrit, and total serum proteins, according to the formulae of Gomez (20). The increase in total renal resistance in the toxemic patients as compared with the normal pregnant patients was highly significant $(p=0.0007)$. The major increase in resistance appeared to be in the afferent segment $(p=0.0001)$ although a significant increase occurred also in venular resistance $(p=0.027)$. In essential hypertension total renal resistance was also greatly increased as compared with the normal $(p=0.0002)$ and once again the afferent segment appeared to be the site of largest increase in resistance.

Tables IV, V, and VI present data obtained from three patients, one with eclampsia, one with pre-eclampsia, and one with essential hypertension. Each of the 3 cases is representative of the groups studied. In Table $\mathrm{V}$ it will be seen that

TABLE IV

Blood pressure, urine flow, renal plasma flow, glomerular filtration rate, filtration fraction, effective osmotic activity, urine concentration of $\mathrm{Na}, \mathrm{Cl}$ and potassium, and total solute loss during osmotic diuresis with mannitol

All flows are calculated per minute per $1.73 \mathrm{~m} .^{2}$

Patient: E. C., Weight: $86 \mathrm{~kg}$., S.A.: $2.01 \mathrm{~m} .^{2}, \quad$ Age: 30 ,

Diagnosis: Eclampsia

\begin{tabular}{|c|c|c|c|c|c|c|c|c|c|c|c|}
\hline Period & $\begin{array}{c}\text { Concurrent } \\
\text { time }\end{array}$ & $\begin{array}{c}\text { Mean } \\
\text { B.P. }\end{array}$ & $\begin{array}{l}\text { Urine } \\
\text { flow }\end{array}$ & $\begin{array}{c}\text { PAH } \\
\text { clearance }\end{array}$ & $\begin{array}{l}\text { Mannitol } \\
\text { clearance }\end{array}$ & F.F. & $\mathrm{Na}$ & $\mathrm{Cl}$ & $\mathbf{K}$ & $\begin{array}{l}\text { Effective } \\
\text { osmotic } \\
\text { activity }\end{array}$ & $\begin{array}{c}\text { Total } \\
\text { solutes }\end{array}$ \\
\hline Prelim & $\begin{array}{r}\min . \\
-30 \text { to } 0 \\
0 \text { to } 10 \\
10 \text { to } 56\end{array}$ & $\begin{array}{c}m m . \mathrm{Hg} \\
155 / 112 \\
\text { I.V. inject } \\
\text { I.V. inject }\end{array}$ & $\begin{array}{c}c c . \\
0.78 \\
\text { on of } 3 \\
\text { on of } 2\end{array}$ & $\begin{array}{c}c c . \\
0 \text { cc. } 25 \% \\
\% \text { manni }\end{array}$ & $\begin{array}{c}c c . \\
0 \text { mannito } \\
\text { itol at } 4.64\end{array}$ & $\begin{array}{l}5.16 \mathrm{c} \\
\mathrm{cc} . / \mathrm{mi}\end{array}$ & $\begin{array}{c}m E q . / L . \\
143 \\
20 \% \mathrm{~N} \\
20 \%\end{array}$ & $\begin{array}{l}m E q . / L . \\
123 \\
\text { aPAH } \\
\text { IaPAH at }\end{array}$ & $\begin{array}{c}m E q . / L \\
12 \\
0.13 \mathrm{cc} .\end{array}$ & $\begin{array}{l}\text { mOsm./L. } \\
890 \\
\text { /min. }\end{array}$ & $\begin{array}{c}\mu O s m . / \min . \\
690\end{array}$ \\
\hline $\begin{array}{l}1 \\
2 \\
3\end{array}$ & $\begin{array}{l}26 \text { to } 36 \\
36 \text { to } 48 \\
48 \text { to } 56\end{array}$ & $\begin{array}{l}173 / 121 \\
181 / 119 \\
200 / 110\end{array}$ & $\begin{array}{l}9.82 \\
9.47 \\
9.73\end{array}$ & $\begin{array}{l}499 \\
402 \\
381\end{array}$ & $\begin{array}{c}105 \\
99 \\
99\end{array}$ & $\begin{array}{l}0.21 \\
0.25 \\
0.26\end{array}$ & $\begin{array}{l}43 \\
45 \\
58\end{array}$ & $\begin{array}{l}43 \\
48 \\
51\end{array}$ & $\begin{array}{l}14 \\
12 \\
10\end{array}$ & $\begin{array}{l}517 \\
512 \\
518\end{array}$ & $\begin{array}{l}5,077 \\
4,849 \\
5,040\end{array}$ \\
\hline
\end{tabular}

TABLE V

Blood pressure, urine flow, renal plasma flow, glomerular filtration rate, filtration fraction, effective osmotic activity, urine concentration of $\mathrm{Na}, \mathrm{Cl}$ and potassium, and total solute loss during osmotic diuresis with mannitol All flows are calculated per minute per $1.73 \mathrm{~m} .^{2}$

Patient: I. M., Weight: $61 \mathrm{~kg} ., \quad$ S.A.: $1.64 \mathrm{m.} .^{2}, \quad$ Diagnosis: Pre-eclampsia

\begin{tabular}{|c|c|c|c|c|c|c|c|c|c|c|c|}
\hline Period & $\begin{array}{c}\text { Concurrent } \\
\text { time }\end{array}$ & $\begin{array}{l}\text { Mean } \\
\text { B.P. }\end{array}$ & $\begin{array}{l}\text { Urine } \\
\text { flow }\end{array}$ & $\begin{array}{c}\text { PAH } \\
\text { clearance }\end{array}$ & $\begin{array}{l}\text { Mannitol } \\
\text { clearance }\end{array}$ & F.F. & $\mathrm{Na}$ & $\mathrm{Cl}$ & $\mathbf{K}$ & $\begin{array}{l}\text { Effective } \\
\text { osmotic } \\
\text { activity }\end{array}$ & $\begin{array}{l}\text { Total } \\
\text { solutes }\end{array}$ \\
\hline Prelim. & $\begin{array}{r}\min . \\
-30 \text { to } 0 \\
0 \text { to } 10 \\
10 \text { to } 94\end{array}$ & $\begin{array}{l}m m . \mathrm{Hg} \\
165 / 112 \\
\text { I.V. inject } \\
\text { I.V. inject }\end{array}$ & $\begin{array}{c}c c . \\
0.21 \\
\text { on of } 2 \\
\text { on of } 2\end{array}$ & $\begin{array}{c}c c . \\
22 \text { cc. } 25 \% \\
5 \% \text { mannit }\end{array}$ & $\begin{array}{l}c c . \\
\text { tol at } 3.33\end{array}$ & $\begin{array}{l}3.66 \mathrm{c} \\
\mathrm{cc} . / \mathrm{min}\end{array}$ & $\begin{array}{c}m E q . / L . \\
84 \\
20 \% \\
20 \%\end{array}$ & $\begin{array}{c}m E q . / L . \\
111 \\
\text { NaPAH } \\
\text { NaPAH at }\end{array}$ & $\begin{array}{c}m E q . / L \\
0.09 \text { cc. }\end{array}$ & $\begin{array}{l}\text { mOsm./L. } \\
812 \\
\text { min. }\end{array}$ & $\begin{array}{c}\mu O s m . / m i n . \\
172\end{array}$ \\
\hline $\begin{array}{l}1 \\
2\end{array}$ & $\begin{array}{l}37 \text { to } 48 \\
48 \text { to } 61\end{array}$ & $\begin{array}{l}166 / 112 \\
160 / 113\end{array}$ & $\begin{array}{l}6.83 \\
6.45\end{array}$ & $\begin{array}{l}459 \\
425\end{array}$ & $\begin{array}{l}81 \\
70\end{array}$ & $\begin{array}{l}0.18 \\
0.16\end{array}$ & $\begin{array}{l}47 \\
45\end{array}$ & $\begin{array}{l}41 \\
42\end{array}$ & & $\begin{array}{l}490 \\
480\end{array}$ & $\begin{array}{l}3,347 \\
3,096\end{array}$ \\
\hline
\end{tabular}

TABLE VI

Blood pressure, urine flow, renal plasma flow, glomerular filtration rate, filtration fraction, effective osmotic activity, urine concentration of $\mathrm{Na}, \mathrm{Cl}$ and potassium, and total solute loss during osmotic diuresis with mannitol All flows are calculated per minute per $1.73 \mathrm{m.}^{2}$

Patient: R. B., Weight: $52 \mathrm{~kg} ., \quad$ S.A.: $1.48 \mathrm{~m} .^{2}, \quad$ Diagnosis: Essential hypertension

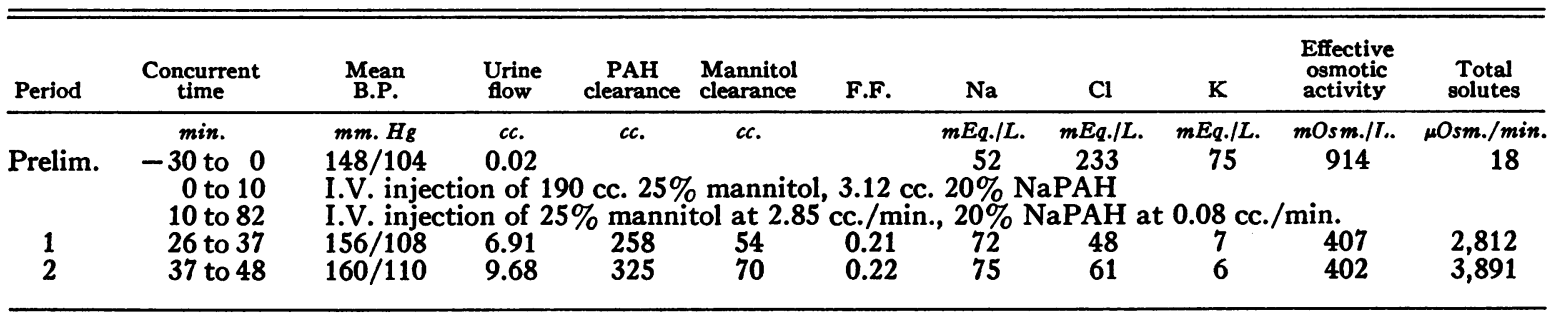


during the study there was a rise in the systolic blood pressure without a significant change in the diastolic blood pressure. It seems unlikely that this rise in blood pressure was due to intravenous injection of mannitol since increase of comparable magnitude did not occur in other patients studied.

\section{DISCUSSION}

Of particular interest is the failure to demonstrate in toxemia of pregnancy a consistent abnormality in the renal handling of sodium and chloride during osmotic diuresis with a nonelectrolyte. During mannitol diuresis induced in the hydropenic state in normal individuals the concentrations of sodium and chloride in the urine are relatively constant irrespective of the rate of urine flow $(5,21)$. The constancy of concentration is thought to reflect the maximum concentration difference which the proximal tubule is capable of achieving between plasma and tubular fluid. However, the concentration difference may be altered by varying the physiological conditions of the experiment, such as loading with sodium salts of various inorganic acids (22), section of the splanchnic nerve (23), or infusion of epinephrine (24). Tarail (25) induced osmotic diuresis in patients with edema of congestive heart failure and cirrhosis of the liver, and demonstrated that the losses of $\mathrm{Na}$ per unit of excreted glucose were considerably smaller than the losses which occurred in the same patients during recovery from the edematous state. Recalculation of their data showed that the difference in $\mathrm{Na}$ concentration between proximal tubular fluid and plasma was considerably greater while edema was present than was observed in the same subjects when free of edema. The reason for the lack of agreement between their observations and those presented here are not apparent. It may be that the mechanism of edema formation varies with differing underlying etiological factors or that the patients studied by Tarail and his associates (25), and these reported here, were in different stages of edema formation. The absence of a defect in the concentrating mechanism for sodium in toxemia of pregnancy does not absolve the kidneys from being at fault in the accumulation of edema-rather it indicates that the retention of sodium and chloride is not associated with the ability of the proximal nephron to abstract these ions from the proximal tubular fluid against a greater concentration difference than that which is achieved in normal subjects.

It is not possible to determine with absolute certainty whether deviation from the normal relationship between flow and load observed in the edematous toxemic subjects was due to a concentration defect or to the greater availability of water for excretion. The patients with essential hypertension were no more edematous than their counterparts with normal blood pressure, so it seems unlikely that the larger volume of water excreted by them could be attributed to the availability of excessive quantities of water. In the cases of toxemia, on the other hand, marked edema was usually present and it is conceivable that edema fluid was available to the kidneys for excretion with the consequence that significant deviations from the normal flow-load relationship occurred. However, since some patients with marked edema showed no deviation from the normal response there is no reason to believe that the mere presence of edema results in the availability of additional water for excretion. Reference to Tables IV and V, which present data obtained in studies on edematous patients, reveals that in neither of these subjects was there any abnormality in the water conservation mechanism. On the other hand, it is possible that additional water is available for excretion only during spontaneous diuresis. As has been pointed out above, all patients were studied as soon after admission as possible and it is probable that none was experiencing spontaneous diuresis during the loading procedure. We believe, therefore, that the abnormality in flow-load relationship is indicative of a concentration defect in these subjects.

Studies of renal hemodynamics in toxemia of pregnancy have indicated that in the majority of cases glomerular filtration rate is depressed (816). It was pointed out, however, that most of these investigations were carried out after treatment had been instituted and many after the acute phase of illness had subsided. The present data, obtained before institution of specific therapy in all but two instances, are in general agreement with the above studies. Renal blood flow has been found by some investigators to be normal or only slightly depressed in the majority of cases $(8,10$, $17,18)$, and by others to be more markedly de- 
pressed $(9,11,15,16)$. The present study shows that in the acute state the mean values for renal plasma flow in toxemic subjects is reduced when compared with normal pregnant subjects in a comparable stage of gestation, but the reduction is less significant than is the reduction of filtration rate.

Reports of renal hemodynamics in cases of essential hypertension in pregnancy are less numerous. It has been found that renal plasma flow is reduced without much alteration in glomerular filtration rate $(8,16)$. In the present study the values for both renal plasma flow and glomerular filtration rate were significantly depressed in comparison with the figures for the normal pregnant patients. The depression was more marked in renal plasma flow than in glomerular filtration rate.

Calculation of renal vascular resistances using the formulae of Gomez (20) is based on the assumption that glomerular membrane permeability is not impaired. It has been claimed by Bell (26) that in eclampsia there may be an increase in the thickness of the glomerular basement membrane. Sheehan (1) and others (2) believe that this pathologic change does not occur in pre-eclampsia and is rarely encountered in eclampsia. Thus it is probable that the values assumed for the gross permeability coefficient in all cases, with the possible exception of the two with eclampsia, are correct. Another source of error in calculation of renal resistance is the presence of proteinuria. However, if it is assumed that all protein in the urine is filtered at the glomerulus, simple calculation shows that with the usual amount of protein lost in the urine in toxemia or essential hypertension ( 1 to 4 grams per 24 hours) the concentration of protein in the glomerular filtrate does not exceed $20 \mathrm{mgm}$. per $100 \mathrm{cc}$. The oncotic pressure and change in viscosity exerted by this minute amount of protein is negligibly small and probably introduces no major error in the calculation of the distribution of resistance to blood flow in the kidney. Finally venous pressure has been shown to be normal in toxemia (27) so that the assignment of the usual value to $P v$. in Gomez' formula probably introduces no error. The calculations presented in this report indicate that in toxemia and essential hypertension associated with pregnancy the major resistance to the flow of blood is in the afferent segment. Kenney (15) arrived at similar conclusions although his methods were different from those presented here. The values obtained here in cases of essential hypertension in pregnancy are in agreement with the data of Gomez (20) who found that the major site of increased resistance in non-pregnant subjects with essential hypertension was in the afferent segment.

\section{SUMMARY AND CONCLUSIONS}

1. A study of excretion of electrolytes and water and renal hemodynamics during osmotic diuresis with mannitol in hydropenia was carried out on 8 patients with pre-eclampsia, 2 with eclampsia and 4 with essential hypertension associated with pregnancy.

2. It was not possible to demonstrate any abnormality in the renal handling of $\mathrm{Na}$ and $\mathrm{Cl}$ in cases of abnormal pregnancy.

3. Impairment of conservation of water per unit of excreted solute load was present in several cases of hypertension and toxemia.

4. Renal plasma flow (PAH clearance) and glomerular filtration rate (mannitol clearance) were reduced as compared to values obtained on normal subjects in the same stage of pregnancy.

5. Renal vascular resistance was increased in the abnormal cases mainly as a result of increase of the afferent segment resistance.

\section{REFERENCES}

1. Sheehan, H. L., Pathological lesions in the hypertensive toxemias of pregnancy; in Toxemias of Pregnancy, Human and Veterinary. Ciba Foundation Symposium, The Blakiston Company, Philadelphia, 1950 , p. 16.

2. Dieckmann, W. J., The toxemias of pregnancy, 2nd Edition, St. Louis, The C. V. Mosby Company, 1952 , p. 71.

3. Smith, G. V., and Smith, O. W., Internal secretions and toxemia of late pregnancy. Physiol. Rev., 1948, 28, 1.

4. Rapoport, S., Brodsky, W. A., West, C. D., and Mackler, B., Urinary flow and excretion of solutes during osmotic diuresis of hydropenic man. Am. J. Physiol., 1949, 156, 433.

5. Brodsky, W. A., The determination of water and electrolyte excretion during osmotic diuresis in hydropenic man; in Methods in Medical Research, A. C. Corcoran, ed. Vol. 5, Chicago, Yearbook Publishers, Inc., 1952, p. 192. 
6. Assali, N. S., Kaplan, S. A., Fomon, S. J., Douglass, R. A., and Tada, Y., The effect of high spinal anesthesia on the renal hemodynamics and the excretion of electrolytes during osmotic diuresis in the hydropenic normal pregnant woman. J. Clin. Invest., 1951, 30, 916.

7. Chesley, L. C., Kidney function in the normal and toxemic pregnant woman. M. Clin. North America, 1951, 35, 699.

8. Corcoran, A. C., and Page, I. H., Renal function in late toxemia of pregnancy. Am. J. M. Sc., 1941, n.s. 201, 385.

9. Dill, L. V., Isenhour, C. E., Cadden, J. F., and Schaffer, N. K., Glomerular filtration and renal blood flow in the toxemias of pregnancy. Am. J. Obst. \& Gynec., 1942, 43, 32.

10. Wellen, I., Welsh, C. A., and Taylor, H. C., Jr., The filtration rate, effective renal blood flow, tubular excretory mass and phenol red clearance in specific toxemia of pregnancy. J. Clin. Invest., 1942, 21, 63.

11. Kariher, D. H., and George, R. H., Toxemias of pregnancy and the inulin-diodrast clearance tests. Proc. Soc. Exper. Biol. \& Med., 1943, 52, 245.

12. Schaffer, N. K., Dill, L. V., and Cadden, J. F., Uric acid clearance in normal pregnancy and preeclampsia. J. Clin. Invest., 1943, 22, 201.

13. Chesley, L. C., and Williams, L. O., Renal glomerular and tubular function in relation to the hyperuricemia of pre-eclampsia and eclampsia. Am. J. Obst. \& Gynec., 1945, 50, 367.

14. Odell, L. D., Renal filtration rates in pregnancy toxemia; inulin and exogenous creatinine. Am. J. M. Sc., 1947, n.s. 213, 709.

15. Kenney, R. A., Lawrence, R. F., and Miller, D. H., Hrmodynamic changes in the kidney in "toxæmia of late pregnancy." J. Obst. \& Gynæc., Brit. Emp., 1950, 57, 17.

16. De Alvarez, R. R., Glomerular filtration rates, renal plasma flow, and sodium and water excretion in pregnancy toxemia. Am. J. Obst., \& Gynec., 1950, 60, 1051.

17. Chesley, L. C., Connell, E. J., Chesley, E. R., Katz, J. D., and Glisson, C. S., The diodrast clearance and renal blood flow in toxemias of pregnancy. J. Clin. Invest., 1940, 19, 219.

18. Turner, H., and Houck, R., Renal hemodynamics in the toxemias of pregnancy. Am. J. Obst. \& Gynec., 1950, 60, 126.

19. Fisher, R. A., Statistical methods for research workers : 6th Edition, Edinburgh, Oliver and Boyd, 1936.

20. Gomez, D. M., Evaluation of renal resistances with special reference to changes in essential hypertension. J. Clin. Invest., 1951, 30, 1143.

21. West, C. D., and Rapoport, S., Urine flow and solute excretion of the hydropenic dog under 'resting' conditions and during osmotic diuresis. Am. J. Physiol., 1950, 163, 159.

22. Rapoport, S., and West, C. D., Ionic antagonism: effect of various anions on chloride excretion during osmotic diuresis in the dog. Am. J. Physiol., 1950, $162,668$.

23. Kaplan, S. A., and Rapoport, S., Urinary excretion of sodium and chloride after splanchnicotomy; effect on the proximal tubule. Am. J. Physiol., 1951, 164, 175.

24. Kaplan, S. A., Fomon, S. J., and Rapoport, S., Effect of epinephrine and L-nor-epinephrine on renal excretion of solutes during mannitol diuresis in the hydropenic dog. Am. J. Physiol., 1952, 169, 588.

25. Tarail, R., Seldin, D. W., and Goodyer, A. V. N., Effects of injection of hypertonic glucose on metabolism of water and electrolytes in patients with edema. J. Clin. Invest., 1951, 30, 1111.

26. Bell, E. T., Renal lesions in the toxemias of pregnancy. Am. J. Path., 1932, 1, 8.

27. Dexter, L., and Weiss, S., Pre-eclamptic and Eclamptic Toxemia of Pregnancy, Boston, Little, Brown \& Co., 1941, pp. 217-302. 